\title{
Translanguaging and Minoritized Language Maintenance: Lessons from Indonesia
}

\author{
MARGANA \\ Department of English Language Education, \\ Faculty of Languages and Arts, \\ Universitas Negeri Yogyakarta, Indonesia \\ RASMAN \\ Department of English Language Education, \\ Faculty of Languages and Arts, \\ Universitas Negeri Yogyakarta, Indonesia \\ rasman@uny.ac.id
}

\begin{abstract}
Translanguaging has been considered as an effective pedagogical approach to foster multilingualism. Previous studies have suggested further that teaching English through pedagogical translanguaging can increase participation of language-minoritized students and thus, promote minoritized language maintenance. However, it remains unclear as to what extent the assumed transformative power of translanguaging allows students to challenge prevailing monolingual ideologies that are gradually pushing minoritized language use to the periphery of society. There is growing evidence that promoting translanguaging practices to language-minoritized students can inadvertently contribute to their language shift from minoritized to majoritized languages (i.e., English and national languages). To maintain and extend this discussion, this article reports on a case study investigating the extent to which translanguaging practices in a tertiary-level EFL class in Indonesia contributes to the efforts to reverse language shift from Javanese to Indonesian and English. The data were drawn from audio-recorded classroom interactions, artefacts of student work and follow-up semi-structured interviews. The findings suggest that translanguaging pedagogy can support minoritized language maintenance only when language inequalities and language hierarchies are transgressed. Furthermore, the effectiveness of translanguaging in maintaining Javanese seemingly relies on whether students have enough proficiency in the Javanese language. Otherwise, the endorsement of translanguaging in this polity may be perceived as an opportunity to practice more dominant languages.
\end{abstract}

Keywords: translanguaging; minoritized languages; language equality; monoglossic ideology; Indonesia

\section{INTRODUCTION}

Translanguaging has recently been advocated and implemented in primary, secondary, and tertiary education to promote language equality and diversity (García \& Seltzer, 2016). Previous studies have reported that allowing students to use their full linguistic repertoire through translanguaging pedagogy can increase their classroom participation (Canagarajah, 2012; Creese \& Blackledge, 2010; García \& Kano, 2014; García \& Sánchez, 2015). The application of translanguaging, therefore, has been associated with the efforts of maintaining minoritized languages. A growing body of research, however, points to a trend of language shift from minoritized to majoritized languages as an inadvertent consequence of endorsing translanguaging practices (e.g. Cenoz \& Gorter, 2017; Mazzaferro, 2018). To maintain and extend this discussion, this article proposes a connection between language-minoritized students' translanguaging practices and the language shift taking place in a monoglossic context. In particular, it reports on a case study of students' translanguaging practices in a tertiary-level EFL classroom in Indonesia. In this polity, monoglossic ideology is reported to be prevalent as shown in how English, Indonesian, and Javanese languages are perceived and practiced as separate entities. Javanese, despite having a relatively large number of speakers, 
is often considered as a minoritized language that is increasingly becoming endangered as its domains of use are gradually being taken over by the use of Indonesian (the national language of Indonesia) and English (Ravindranath \& Cohn, 2014; Vander Klok, 2019; Zentz, 2015; Zen, 2021).

\section{LITERATURE REVIEW}

\section{TRANSLANGUAGING AND MINORITIZED LANGUAGE MAINTENANCE}

As a pedagogical approach, translanguaging allows learners to use their full linguistic repertoire at their own disposal (Canagarajah, 2012; García \& Wei, 2014). From a translanguaging perspective, learners' repertoire does not comprise two (or more) separate language systems but instead, it consists of one language system from which a speaker flexibly draws on any necessary code to produce complex and interrelated language practices for communicative purposes (Creese \& Blackledge, 2010).

Translanguaging is considered as an effective means for "protecting minoritized communities, their languages, and their learners and schools" (Otheguy et al., 2015, p. 283). The application of translanguaging is often associated with the maintenance of minoritized languages in that it allows language-minoritized speakers to "interrogat[e] linguistic inequality" through their flexible use of different linguistic resources in educational contexts (García \& Kano, 2014, p. 261). The term linguistic inequalities here refers to "unequal access to languages, unequal status between languages, and unequal power relations between language users" (Hawkins \& Mori, 2018, p. 6). In this respect, translanguaging, language equality and minoritized language maintenance have often been considered to have a linear or causal relationship.

This claim, however, has lately been challenged by other scholars who are worried that the implementation of translanguaging will threaten language-maintenance efforts. For instance, Cenoz and Gorter (2017), being cautious about the presence of translanguaging, propose the adoption of what they call as sustainable translanguaging, that is, a pedagogical tool that balances the promotion of flexible use of multiple linguistic resources with a breathing space to sustain the use of minoritized languages. The term breathing space (Fishman, 1991) here refers to a space in which minoritized languages are practiced exclusively without the interference of the more dominant languages. Likewise, Jaspers (2018, p. 8) argues further that without such a pedagogical innovation, translanguaging can inadvertently become a dominating force that "prevent[s] transparent debate about what type of language use at school is desirable."

Their concerns seem to stem from the awareness that a monoglossic ideology, an ideological stance which views languages as separate, bounded entities (García, 2009), has become so prevalent in the society that endorsing flexible use of languages might just perpetuate current language shift instead of reversing it. In other words, creating a space for translanguaging at school might not be as transformative if students and teachers still consider English or national languages as the most important, valuable, and appropriate language practice in their specific socio-political contexts. Eventually, this ideology will prevent minoritized languages from broadening their domains of use in communities and school contexts.

In the present study, we aim to maintain and extend this conversation about translanguaging in conjunction with the processes of minoritized language shift and maintenance. While there is now a growing body of research discussing a rapid language shift from minoritized to majoritized languages as an inadvertent consequence of endorsing 
translanguaging practices, most of these studies were conducted in the Global North contexts. Only few studies on this topic were carried out in Asian contexts where English is typically framed as a foreign language while diverse indigenous languages are minoritized.

The latest relevant study conducted in one of the Southeast Asian polities was Nguyen and Hamid's (2021) study of language choices among language-minoritized students in the context of family and community in Vietnam. Their findings suggest that more powerful languages, particularly Vietnamese, the national language, play a role in accelerating language shift among language-minoritized students. In another study, Nguyen (2019, p. 49) interviewed students and their parents about their beliefs, practices, and identities in relation to translanguaging and found out that "the degree of 'inserting' L2 words and L2 communication style into L1 was much higher than the opposite direction." In other words, the students' translanguaging practice has inadvertently contributed to the language shift from the students' L1 to their Vietnamese. Mazzaferro's (2018) study, however, shows different results. It concludes that Filipina/os youth's translanguaging practice positively contributes to the efforts of language shift and maintenance of their heritage languages. That said, although this study focused on Filipina/os, it was situated in Turin, Italy, which might explain the different results between this study and the previous ones.

This limited number of studies focusing on both translanguaging and language maintenance particularly in Southeast Asian contexts has motivated us to undertake research on translanguaging and Javanese language maintenance in Indonesia. The present study is hoped to shed light on the extent to which translanguaging helps to promote language equality and maintain minoritized languages, particularly in the Indonesian polity.

\section{CONTEXT}

Indonesia is the world's second most linguistically diverse country with more than 719 languages (Simsons \& Fenning, 2017) spread across the archipelagic nation. There are three types of language status in this country: national language (i.e. Indonesian), foreign language (e.g. English), and regional/minoritized languages (e.g. Javanese, Sundanese, and Balinese). While Indonesian is taught as a compulsory subject at all levels of education and English is compulsory at least at secondary level, minoritized languages are only optional subjects at primary and secondary level and are even absent at tertiary (Suwarno, 2020). In addition, Indonesian is chosen as the medium of instruction for all subjects except for foreign language classes in which teachers are allowed to use foreign languages to teach the subjects.

As a result, a language shift from the minoritized languages to either English or Indonesian are often reported in the literature (see Arka, 2013; Cohn \& Ravindranath, 2014; Musgrave, 2014). Overall, there are at least 621 minoritized languages in Indonesia that, according to Krauss (1992), are at risk for having fewer than 100,000 speakers. Ravindranath and Cohn's (2014) study suggests further that minoritized languages such as Javanese, despite having a relatively higher number of speakers, are also at risk due to the weak intergenerational transmission. The problem of the language shift from Javanese to national and English languages have been reported in recent studies (see Andriyanti, 2019; Sakhiyya \& MartinAnatias, 2020; Setiawan, 2020; Zentz, 2015). Sociolinguistic, behavioural, and demographic issues are some of the typical factors behind this issue of language shift.

It has been argued that one of the indicators of the ongoing occurrences of language shift is the growing occurrence of code-switching phenomena ( $\mathrm{Yu}, 2005$ ). In Indonesia, a growing body of works has reported the phenomena of code-switching in various contexts including novels/short stories (Martin-Anatias, 2018; Yusuf et al., 2018), radios/televisions (Luciana, 2014), educational settings (Margana, 2013), and presidential speeches (Foster \& Welsh, 2017). These studies capture the phenomenon of either natural or pedagogical code- 
switching. The growing use of code-switching in these multiple domains, despite its potential benefits, can potentially set the stage for language shift because it is typically not followed by an awareness-raising activity of the importance of maintaining linguistic diversity.

Code-switching can be contrasted with translanguaging in that the latter is built upon creativity and criticality (Wei, 2011) of using one's single linguistic repertoire while the former uncritically relies on the assumption that languages are bounded entities that have clear and fixed boundaries (Creese \& Blackledge, 2010). While code-switching is a term that represents an activity of switching from one named language to another, translanguaging holds a view that there is no specific point at which one language ends and another starts because the assumed boundaries between languages are merely a socio-political construction (Canagarajah, 2012; García \& Wei, 2014). In other words, in contrast to translanguaging, code-switching originates from monolingualism, an ideology which might have exacerbated the ongoing processes of language shift.

While the endorsement of code-switching in the classroom is becoming increasingly more popular in Indonesia, the introduction of the use of translanguaging in this context is still in its infancy (Zein, 2020). This is concerning because efforts to maintain minoritized languages have to be started with a move away from pedagogical approaches that might be complicit in maintaining a monoglossic ideology that has exacerbated unequal power relations between languages. Without having an attempt to dismantle such language inequalities between minoritized languages such as Javanese and majoritized languages such as English and Indonesian, chances are, a flexible use of languages will always be perceived as an illegitimate practice. The use of minoritized languages, which have a lower status, will be continuously seen as an inappropriate language practice especially in relation to the learning of languages with a higher status.

\section{THEORETICAL FRAMEWORK}

To understand whether translanguaging practices affect the efforts of minoritized language maintenance, we need to first understand how a shift from minoritized to majoritized languages takes place. The language shift occurs when minoritized languages are spoken in restricted domains of use (Fishman, 1991). Domains of use here refer to multiple contexts such as families, schools, communities, and offices in which a specific language use is considered to be the most appropriate. If a language has multiple domains of use, chances are, its intergenerational transmission can easily occur and thus, the language can be eventually maintained (Fishman, 1991). The shift from minoritized languages to more dominant languages in a particular domain of use can be seen from the extent to which the use of minoritized languages is considered appropriate or legitimate. In educational contexts, we need to understand the extent to which classroom members tolerate students who, in their interactions, incorporate languages, particularly minoritized ones, that are traditionally seen as inappropriate.

To do so, we make use of Myers-Scotton's (1993) markedness model (MM). In this model, language choices in particular settings are considered as either 'unmarked' or 'marked'. The codes chosen by a speaker are viewed as 'unmarked' if these are the codes that are socially expected. In contrast, if a speaker uses a socially unexpected code choice, this practice can be categorized as 'marked'. For example, typically, the use of minoritized languages at home is deemed appropriate by the family members but the reverse is true in educational contexts. By using MM, we can understand the extent to which the use of minoritized languages is legitimized by examining the interactions that occur between speakers in a particular context.

The underlying assumption behind $\mathrm{MM}$ is that every speaker has a natural ability regarding indexicality as an element of their communicative competence (Myers-Scotton \& 
Bolonyai, 2001). The language choices reflect one's rights and obligations in a particular context. When speakers use socially expected code choices, they are maintaining their rights and obligations in their context. However, in other occasions, they might also use 'marked' code choices, or languages that are not expected by their interlocutors, to negotiate their rights and obligations. In this respect, therefore, "examining patterns of unmarked and marked translanguaging may provide information about dominant language ideologies" (Beiler, 2021, p. 112). Thus, in our study, the use of 'marked' or 'unmarked' code choices can reflect the extent to which translanguaging practices are permissible (hence, students' language ideologies). In addition, it can also show whether a particular language is dominating this classroom domain, which, if it is the case, is a sign of a language shift being taking place.

\section{METHODS}

This qualitative case study investigated translanguaging practices in relation to the maintenance of Javanese language and its ongoing shift to Indonesian and English language (majoritized languages). The study was conducted in an English-speaking classroom held in a university in the Javanese Province of Yogyakarta, Indonesia. The qualitative case study (Yin, 2011) was chosen to get richer data on students' translanguaging practices and to find out whether these practices promote or hinder the efforts of creating language equality, which is a crucial element for minoritized language maintenance.

\section{RESEARCH SITE AND PARTICIPANTS}

This study was undertaken in a university in Yogyakarta, Indonesia. We chose this site because we have a convenient access via our private network. This university is currently making efforts to internationalize its campus. To realize this goal, all graduates from this university are expected to have a higher English proficiency at least at the intermediate level. In addition to requiring them to pass an English standardized test, students are also given opportunities to participate in an English-speaking class to make sure they have a good oral command of English, which is deemed important not only in order to compete in the current job market but also in the efforts to build the university's prestige.

Students from all departments in the university were given a choice as to whether to enrol in the class. Those who had registered were divided into classes of 20 students at maximum. Each class had a mix of students from different departments with different levels of proficiency. In the present study, we recruited 20 participants from one of these classes. We chose this class using purposive sampling based on the criteria of language and ethnicity. Table 1 shows the information about the focal participants that are specifically relevant in this study (we use pseudonyms to protect the identities of the participants). 
TABLE 1. Information about the participants

\begin{tabular}{|c|c|c|c|c|c|}
\hline Pseudonym & Age & Gender & $\begin{array}{c}\text { First } \\
\text { language }\end{array}$ & Other languages & $\begin{array}{c}\text { English } \\
\text { proficiency } \\
\text { level (CEFR) }\end{array}$ \\
\hline Umi & 19 & Female & Javanese & $\begin{array}{l}\text { Indonesian } \\
\text { (second language) } \\
\text { English } \\
\text { (third language) }\end{array}$ & Intermediate \\
\hline Pevita & 20 & Female & Javanese & $\begin{array}{l}\text { Indonesian } \\
\text { (second language) } \\
\text { English } \\
\text { (third language) }\end{array}$ & Intermediate \\
\hline Andi & 19 & Male & Javanese & $\begin{array}{l}\text { Indonesian } \\
\text { (second language) } \\
\text { English } \\
\text { (third language) } \\
\text { Japanese } \\
\text { (fourth language) }\end{array}$ & Intermediate \\
\hline
\end{tabular}

The classroom in which this study took place comprised students from three out of seven different faculties: Languages and Arts, Mathematics and Natural Sciences, and Engineering. Some came from English language department and had a slightly higher level of English proficiency. There were 12 meetings held in this teacher-led classroom in total and each meeting lasted for ninety minutes. Participants were speaking three languages: Javanese, Indonesian, and English. In these classes, there was no specific rule given by the instructor as to whether students had to use English exclusively. Thus, the teacher's and students' language practices in a way reflect their language ideologies. This classroom context suits the study's purpose well, that is, to find out whether students adopt a monoglossic ideology and how it is connected to translanguaging practices and Javanese language maintenance.

\section{DATA COLLECTION AND ANALYSIS}

The data were collected through classroom observation with audio recordings, analyses of artefacts of student work, and follow-up semi-structured interviews. In this study, the recording was taken from one of the meetings in which the students were asked to present any topic and then discuss it with their peers in pairs. The meeting lasted for 90 minutes which were divided into a presentation segment (around seven minutes at maximum per presentation) and discussion segment (20 minutes after all students have finished presenting their topic). Students were also allowed to give comments on the topic in each segment. To understand more deeply about students' language practices, artefacts of student work in the form of PowerPoint documents were gathered. A 20- to 30-minute semi-structured interview with each participant was also conducted. The interviews were conducted either in Indonesian or English (sometimes both) depending on the participants.

After being transcribed, the classroom interaction data were then analysed using the following steps. First, the transcript was read multiple times to make sure that we understand the conversation more deeply and closely. After that, we noted all instances where the students' language choices were 'marked' and where they were 'unmarked'. Then, we categorized them based on which named language they are traditionally associated with (i.e., Indonesian, English, or Javanese) to know whether a specific language use is perceived as 'marked' or 'unmarked'. This transcript was then connected to the theoretical concepts of translanguaging, language equality, and language shift/maintenance. The interpretation of the transcript was focused on finding out whether Javanese code choices in the translanguaging excerpts were driven by a specific language ideology. These interpretations were then triangulated with the 
data derived from the analyses of artefacts of student work as well as the interviews with the relevant participants. The interview data were analysed thematically following three steps: open, axial, and selective coding.

\section{FINDINGS AND DISCUSSION}

\section{MONOGLOSSIC IDEOLOGY AND MINORITIZED LANGUAGE MAINTENANCE}

Monoglossic ideology often prevails in a foreign language context. It permeates into educational settings and foreign language learners in particular are more susceptible to it. The present study found that learners' susceptibilities are evident in how they used Javanese, Indonesian and English.

Extract 1 shows how Andi complained about Umi's 'incorrect' pronunciation of an English word, claiming that her Javanese accent was the cause.

\section{Extract 1 \\ 1 Umi : There is a masjid gedhe kauman so it's older than the keraton before they built the keraton, \\ 2 Andi : The great mosque... \\ 3 Umi : Yea...the great mosque... Mosque not moskyu \\ 4 Andi : Javanese accent...}

In this exchange, Andi was oriented towards a monoglossic ideology which was evident when he translated Umi's Javanese words 'masjid gedhe kauman' (Line 1) into English as 'the great mosque' (Line 2). It shows that Andi considered Umi's translanguaging practice and her use of Javanese as a marked language practice. Although Umi's use of Javanese did not cause communication difficulties, Andi insisted that the phrase be translated into English. His ideological stance is confirmed in the interview in which he asserted that English should be strictly separated from Javanese in the classroom.

\footnotetext{
"I believe 'English-only' is the most effective method because it will force us to communicate in the classroom ..." (Andi)
}

Furthermore, Line 4 also shows Andi's explicit ideological stance as he pointed out that Umi's Javanese accent was the cause of her 'incorrect' pronunciation of the word 'mosque'. Had Andi been oriented towards a multilingual ideology, he would have recognised the significance of intelligibility (Li \& Chen, 2019), embraced a wide variety of pronunciations and focused instead on whether he understood what was said (Murphy, 2014; Sewell, 2016). He admitted in the interview that he considered the American accent as 'the most important accent' and that the Javanese accent will bring a negative effect to English language learning.

\footnotetext{
"In my opinion, American accent is the most important accent because it is commonly used from elementary to tertiary education. When people with a Javanese accent speak English, um, it is very influential. I mean, they already have an accent that is already known by their tongue so when learning a new accent, they will not speak English perfectly because it is influenced by the previous accent they have mastered, which is the Javanese accent." (Andi)
}

Intriguingly, Umi accepted Andi's 'correction' and even hesitantly 'corrected' her own pronunciation (Line 3). This phenomenon is similar to Wang's (2019) findings that suggest that language learners are likely to adjust their language to conform to a mainstream language 
that their peers use. In this case, Umi was aligning herself with a monoglossic ideology that is adopted by her peer who considered her Javanese accent to be a marked accent.

A similar case is also found in Extract 2, in which Umi's way of pronouncing the word 'mosque' was, again, criticized. Now, it was Mala who insisted that Umi accepts her correction. She even repeated Umi's correction twice (line 4 and 7). This peer pressure seems to affect Umi as shown in line 3 where she attempted to 'correct' her own way of pronouncing the word with an unmarked accent as expected by her peers.

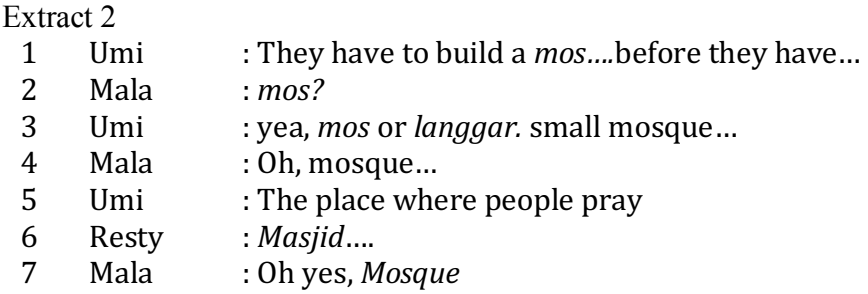

Interestingly, in line 5, Resty, the teacher translated the word into Indonesian ('masjid'). At first glance, it seems that she exerted a heteroglossic ideology to show her students that languages other than English were allowed to be used in the classroom. However, a closer look shows that she did not fully adopt this ideology. Her language choice, which is Indonesian language and not Javanese, seems to imply that she considered Javanese as a marked code. It can be contrasted with Umi's choice of a Javanese word 'langgar' which is similar in meaning to the word 'masjid'. Resty's view that Javanese is an illegitimate language in the classroom is confirmed by the interview data.

"Javanese language is highly discouraged. I believe that this language may be used only, and only if, it cannot be expressed in Indonesian or English.” (Resty)

The monoglossic ideology can also be identified in Extract 3. Interestingly, while Extract 1 shows an implicit ideology towards the exclusion of Javanese language, Extract 3 reflects a more explicit opposition towards the use of Indonesian language.

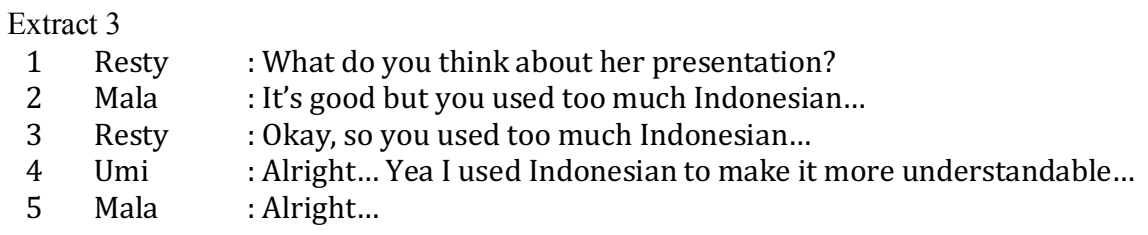

In this exchange, Resty asked for Mala's opinion on Umi's presentation. Surprisingly, even though Mala's overall assessment on Umi's presentation was quite positive, meaning that she understood the presentation well, she still complained about Umi's use of Indonesian language in her presentation (Line 2). Umi defended her use of Indonesian language, which for her was an unmarked language choice. She argued that her use of Indonesian was intentionalshe used her whole linguistic repertoire (English, Indonesian, and Javanese) to make meaning and communicate more effectively with her peers (Line 4).

The three extracts above are evidence that language separation or a monoglossic ideology still prevails in educational contexts in Indonesia. It is unsurprising that the use of students' first language is seen as an illegitimate language practice in English classrooms in Indonesia as reflected in the extracts above. All of our focal participants agreed that the three languages should be used separately and that there is a particular language hierarchy in which English is considered as the most important while Javanese is the least useful language. Below is an example of such a view. 


\begin{abstract}
"Well, especially in this era of globalization, among the three languages, I think the most valuable is English, because the use of English can give new insights and more opportunities. The least valuable language for me is the Javanese language because it cannot help us survive in the era of globalization because they cannot help us communicate on a global scale." (Andi)
\end{abstract}

This view can threaten the maintenance of minoritized languages such as Javanese because it may encourage the use of English in domains where a minoritized language is traditionally practiced and considered to be the most appropriate code. This finding is in line with previous studies, which find that Javanese language, despite its relatively large speech community, is likely to be endangered because its domains of usage are being taken over by majoritized languages (Adelaar, 2010; Poedjosoedarmo, 2006; Ravindranath \& Cohn, 2014). Minoritized languages such as Javanese are commonly used only in informal settings such as at home with their family members (Suryadinata et al., 2003).

In our study, Umi admitted that the domains of use for Javanese are decreasing and that this situation has made her unable to be really proficient in the Javanese language.

\footnotetext{
"I feel that I master English and Indonesian more than Javanese. I think it is because these two languages are used more often at school, at work and in everyday life. I sometimes feel embarrassed because I am a Javanese but I don't know the Javanese language well." (Umi)
}

Another striking point that can be taken is that this monoglossic ideology seems to be imposed not only by education institutions or teachers but also students themselves. The extracts discussed above show that students were somewhat equally active in suppressing the use of Javanese in the classroom. While previous studies highlight teachers' role in limiting the use of languages other than English (Kirkpatrick, 2014; Martínez et al., 2014; Shin, 2004; Wang \& Kirkpatrick 2013), the extracts above illustrate how students actively and explicitly advocated the monolingual norm.

\title{
CAN TRANSLANGUAGING SAVE MINORITIZED LANGUAGES?
}

In this part, we will firstly show other cases in which the Javanese language was perceived by the students as the less preferred language in the conversation compared to the Indonesian language. The following extract demonstrates how the use of Indonesian was acceptable when learners performed translanguaging.

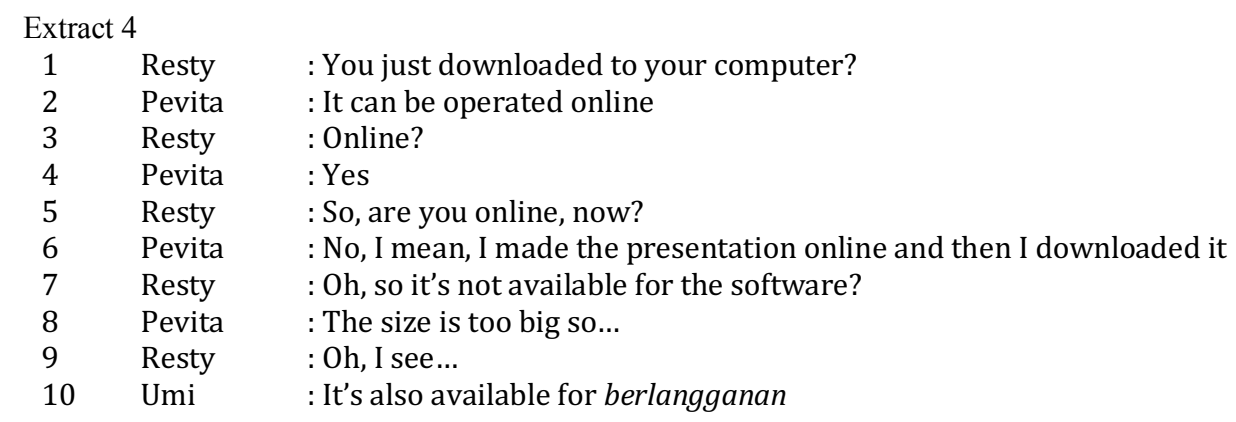

In this exchange, Umi used an Indonesian word 'berlangganan' (subscribing). This use of Indonesian word did not seem to make other students nor the teacher feel 'bothered' ('unmarked' code choice) even though it can be clearly seen that Pevita and Resty only used English words in the previous lines. In another exchange (Extract 5), Umi also used another Indonesian word and, again, no one immediately interrupted her and criticized her use of Indonesian language. 
Extract 5

1 Umi : That's right. It symbolizes the mata angin. You know, north, south, east, and west.

2 And each has its own meaning but I forget the meaning...

No interruption was given after Umi said the words 'mata angin' during her presentation. After this extract, her friends continued listening to her presentation as if nothing had happened. It can be contrasted with the reaction she received when she spoke in Javanese language (Extract 1 and 2). Extract 4 and 5 show that, unlike the use of Javanese, the use of Indonesian is comparatively more welcomed. It is also interesting to note that the criticism of the use of Indonesian was delayed until the presentation was finished. It is in contrast with the immediate disapproval of the use of Javanese, which was asserted right after it was spoken. It indicates that, unlike the use of Javanese, the reaction to the use of Indonesian is relatively more relaxed. That said, the domain of usage of the Indonesian language is fairly narrower than that of English as reflected in Extract 3.

The present study which finds that Javanese language has limited domains of usage can be used as a basis for future policymaking aiming to support the maintenance of minoritized languages. Therefore, it seems reasonable to suggest that the implementation of translanguaging might not bring a significant support (if not cause a setback) to the efforts of constructing language equality unless the monoglossic ideology is not widely prevalent and highly influential among students in the classroom.

Unless it is carefully and strategically implemented, translanguaging is also likely to create more resistance towards the use of Javanese language. Translanguaging could potentially threaten minoritized language because it can be taken as the opportunity for students to use majoritized languages more frequently (Lewis et al., 2012). In the case of Indonesia, the majoritized languages which are likely to be favourable are Indonesian and English languages. Meanwhile, Javanese will gradually lose more domains of use.

This study does not suggest that translanguaging is a completely inappropriate pedagogical approach. Instead, this study indicates that language equality is probably better perceived not only as the end goal of creating a translanguaging space but also as the prerequisite for translanguaging practices to take place within this space (see Fig. 1). In other words, we have to make sure that students have enough proficiency in minoritized languages and are critically aware of the importance of using the minoritized language before letting them use the translanguaging space provided (Rasman, 2018). 


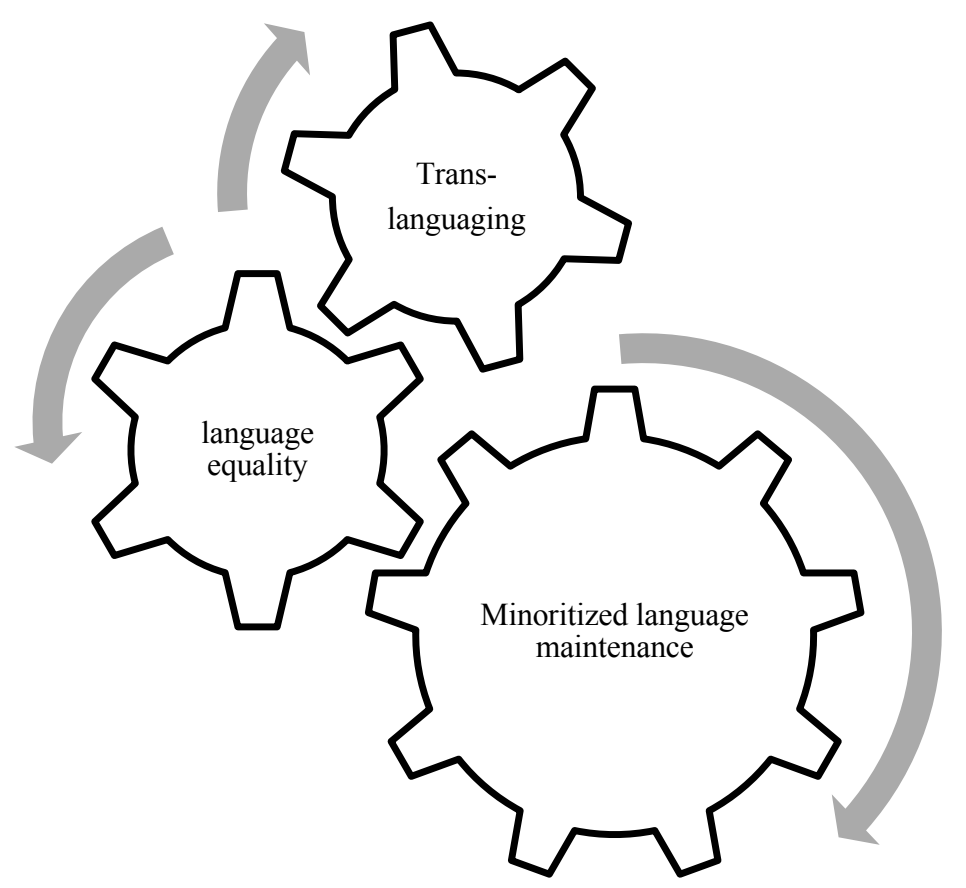

FIGURE 1. Language equality as a means and goal of creating the translanguaging space

Figure 1 shows how translanguaging is situated in the processes of minoritized language maintenance. What we propose here is that the relationship between translanguaging and language equality is not linear, nor is it a causal one. Instead, it is the dynamic relationship that occurs between the two: language equality boosts the translanguaging practice and in turn, the translanguaging practice improves language equality.

If some degree of language equality is a prerequisite for translanguaging to take place, then, what should we do before we actually implement a formal translanguaging? The next section will discuss the implication of this study. Particularly, we will discuss what policymakers and teachers can do to maximize the implementation of translanguaging.

\section{WHEN SHOULD TRANSLANGUAGING BE IMPLEMENTED AND WHEN SHOULD IT BE POSTPONED?}

Although the multilingual turn (May, 2014) has provided us with a crucial step towards language equality and diversity (Lee, 2019), we argue that a strict dichotomy between monolingualism and multilingualism might close the space for researchers to examine the possibility of strategically combining the use of monolingualism and multilingualism in the classroom. We think that it is not an either-or situation: either we adopt a multilingual norm to maintain language diversity or adhere to monolingualism with the consequence of perpetuating the dominance of a majoritized language. As shown in our findings, it turns out the use of translanguaging in foreign language contexts such as in Indonesia is useful only to a certain extent. It seems that learners need to be taught Javanese more intensively at first until they have a higher proficiency prior to providing them with a translanguaging space. They also need more time and space to build their critical awareness on the importance of using this minoritized language. While they are improving their proficiency in and building awareness of Javanese language, teachers need to strategically restrain themselves from using too many English and Indonesian words. In short, for the Indonesian context, we believe in the importance of transitional bilingualism. Javanese language has to be taught separately at first to give students more space to add Javanese into their whole linguistic repertoire. 
However, it should be noted that even though teachers are recommended to use Javanese exclusively, they should still bear in mind that this strategy is used with an ultimate goal of preparing students for a fuller and more holistic bilingual education program. It can be contrasted with, for instance, teachers of minoritized language classes who are typically influenced by a language separation view rooted in a monoglossic ideology (García \& TorresGuevara, 2010). In this respect, teachers' end goal of teaching this minoritized language is a monolingual practice where students are not encouraged to use Javanese and English simultaneously in a conversation.

In the transitional bilingual education that we imagine, teachers are fully aware of language inequality and they will be able to decide when they think their students are proficient enough in the minoritized language and are ready to optimally make use of the translanguaging space. Teachers' ultimate goal is to make students more aware of the current unequal status between English and Javanese. Their purpose is to make sure that students will eventually use both languages flexibly. The success of this transitional bilingual education depends largely on teachers' ability to raise their students' awareness on the importance of using their minoritized languages. Another factor that might be crucial is whether collaboration among different language teachers (English, Indonesian, and Javanese) exists. These teachers can collaborate to help students experience a fuller translanguaging practice.

This study is, to a certain extent, in line with García and Lin's (2016) notion of strong and weak versions of translanguaging. We believe that in the Indonesian context or other similar contexts, a strong version of translanguaging, which endorses a radical shift from a term called named languages into a term called full repertoire, cannot be directly applied due to the prevailing monoglossic ideology in the society. To ensure that minoritized languages can be preserved, a weaker version of translanguaging, as discussed above, is needed. In this case, named minoritized languages still need to have their own exclusive space to develop without the influence of a monoglossic ideology. However, at the same time, the boundaries of all named languages have to be gradually softened.

Indonesian policymakers, however, have seemingly not considered this type of multilingual education (Cahyani et al., 2018; Zein, 2018). In the context of higher education institution in particular, there has been fewer efforts to teach minoritized languages and multilingualism. Most institutions are currently focusing only on an internationalization program (Abduh et al., 2018) which results in the stronger hegemony of English since it endorses English as the only legitimate language for any international communication. Policymakers have tried to focus their attention on the elementary schools when it comes to saving minoritized languages. In elementary schools, English has been dropped as a compulsory subject because it is believed to have endangered the acquisition of Indonesian language and minoritized languages.

Those instances show that even though policymakers seem to be aware of the importance of preserving minoritized languages, their policies still adhere to a monoglossic ideology. Their end goal is to improve students' language skills in three separate named languages instead of aiming at leveraging their linguistic resources. So, when should translanguaging be implemented? The answer might be simple: when there has been some degree of equality among languages. The reverse is true to answer the question of when translanguaging should be postponed. Looking at what is happening in Indonesia, it seems reasonable to focus more on improving students' minoritized language proficiency first before employing a translanguaging approach. 


\section{CONCLUSION}

This study has attempted to examine the feasibility of applying translanguaging approach in contexts where English is taught as a foreign language and tried to find out if this approach supports the efforts of maintaining minoritized languages. This study found that, in line with the findings from previous studies, translanguaging is a potential approach that is likely able to support language equality and thus, promote minoritized language maintenance.

However, our finding also suggests that translanguaging should be applied in the Indonesian contexts (and other similar EFL contexts) with caution. Contrary to popular belief, our study seems to suggest that the implementation of a translanguaging approach will not automatically help the maintenance of minoritized languages. The success of a translanguaging approach in maintaining minoritized languages depends on the degree of language inequality between majoritized languages (i.e., English/Indonesian) and minoritized languages (e.g. Javanese). If students have a strong belief in a monoglossic ideology, in which English has a much higher status than minoritized languages, it is unlikely that they will take advantage of the translanguaging space provided for practicing translanguaging. Instead, they will use this space to use majoritized languages more often.

Therefore, it is safe for us to say that we should no longer see translanguaging as a onesize-fit-all pedagogical approach for creating language equality irrespective of the contexts where the educational institutions operate. We believe the relationship between translanguaging and language equality is not linear. We should start re-examining our assumption that translanguaging approach is the solution to language inequality regardless of the contexts. Our study suggests that the relationship between translanguaging and language equality is better seen as a dynamic one. On one hand, language equality is the end goal of applying a translanguaging approach. On the other hand, the former is also the prerequisite for the latter to occur. The application of translanguaging, therefore, is really context-dependent. We should look more closely at the degree of language inequality occurring in a particular context.

With that being said, we are aware that this study has not fully answered all questions on this underdeveloped topic of the relationship between a translanguaging practice (and pedagogy) and minoritized language maintenance. Further studies are needed to examine more closely the relationship between the two. Our preliminary study on this topic needs to be supported with studies that use a larger number of participants and a longer time frame focusing on the problems of language maintenance in the contexts of home, school, and community coupled with the emerging influence of globalization and technological development (Hamat $\&$ Hassan, 2019). These factors need to be considered in future studies so that we can be much more confident in claiming the effects of translanguaging particularly in relation to minoritized language maintenance in EFL contexts.

\section{REFERENCES}

Abduh, A., Rosmaladewi, R. \& Basri, M. (2018). Internationalization, awareness and commitment of Indonesian higher education. New Educational Review. 51(1), 162-171.

Adelaar, A. K. (2010). Language documentation in the West Austronesian world and Vanuatu: An overview. In Florey, M. J. (Ed.). Endangered languages of Austronesia (pp. 12-41). Oxford: Oxford University Press.

Andriyanti, E. (2019). Language shift among Javanese youth and their perception of local and national identities. GEMA Online ${ }^{\circledR}$ Journal of Language Studies. 19(3), 109-125.

Arka, I. W. (2013). Language management and minoritized language maintenance in (eastern) Indonesia: Strategic issues. Language Documentation and Conservation. 7, 74-105.

Beiler, I. R. (2021). Marked and unmarked translanguaging in accelerated, mainstream, and sheltered English classrooms. Multilingua. 40(1), 107-138. 
Cahyani, H. de Courcy, M. \& Barnett, J. (2018). Teachers' code-switching in bilingual classrooms: Exploring pedagogical and sociocultural functions. International Journal of Bilingual Education and Bilingualism. 21(4), 465-479.

Canagarajah, S. (2012). Translingual practice: Global Englishes and cosmopolitan relations. New York: Routledge.

Cenoz, J. \& Gorter, D. (2017). Minoritized languages and sustainable translanguaging: Threat or opportunity? Journal of Multilingual and Multicultural Development. 38(10), 901-912.

Cohn, A. C. \& Ravindranath, M. (2014). Local languages in Indonesia: Language maintenance or language shift. Linguistik Indonesia. 32(2), 131-148.

Creese, A. \& Blackledge, A. (2010). Translanguaging in the bilingual classroom: A pedagogy for learning and teaching. The Modern Language Journal. 94, 103-115.

Fishman, J. A. (1991). Reversing language shift: Theoretical and empirical foundations of assistance to threatened languages (Vol. 76). Bristol: Multilingual Matters.

Foster, M. \& Welsh, A. (2017). The controversial code-switching of an Indonesian President. South East Asia Research. 25(4), 395-411.

García, O. (2009). Bilingual Education in the 21st Century: A Global Perspective. Chichester: Wiley-Blackwell

García, O. \& Kano, N. (2014). Translanguaging as process and pedagogy: Developing the English writing of Japanese students in the US. In Conteh, J. \& Meier, G. (Eds.). The multilingual turn in languages education: Opportunities and challenges (pp. 258-277). Bristol: Multilingual Matters.

García, O. \& Lin, A. M. Y. (2016). Translanguaging in bilingual education. In García, O. \& Lin, A. M. Y. (Eds.). Bilingual and multilingual education (pp. 1-14). Dordrecht: Springer.

García, O. \& Sánchez, M. (2015). Transforming schools with emergent bilinguals: The CUNY-NYSIEB project. In Dirim, I., Gogolin, I., Knorr, D., Krüger-Potratz, M., Lengyel, D., Reich, H. \& Weiße, W. (Eds.). Intercultural education: Festchrift for Ulla Neumann (pp. 80-94). Berlin, Germany: Waxmann-Verlag.

García, O. \& Seltzer, K. (2016). The translanguaging current in language education. In Kindenberg, B. (Ed.). Flerspråkighet som resurs [Multilingualism as a resource] (pp. 19-30). The Hague: Liber.

García, O. \& Torres-Guevara, R. (2010). Monoglossic ideologies and language policies in the education of U.S. latinas/os. In Murillo, E., Villenas, S., Galván, R. T., Muñoz, J. S., Martínez, C. \& Machado-Casas, M. (Eds.). Handbook of Latinos and Education: Research, theory and practice (pp. 182-194). Mahwah: Lawrence Erlbaum.

García, O. \& Wei, L. (2014). Translanguaging: language, bilingualism and education. New York: Palgrave Macmillan.

Hamat, A. \& Hassan, H. A. (2019). Use of social media for informal language learning by Malaysian University students. 3L: Language, Linguistics, Literature ${ }^{\circledR}$. 25(4), 68-83.

Hawkins, M. R. \& Mori, J. (2018). Considering "trans-" perspectives in language theories and practices. Applied Linguistics. 39(1), 1-8.

Jaspers, J. (2018). The transformative limits of translanguaging. Language \& Communication. 58, 1-10.

Kirkpatrick, A. (2014). Afterword. In Barnard, R. \& McLellan, J. (Ed.). Code-switching in university Englishmedium classes: Asian perspectives (pp. 214-221). Bristol: Multilingual Matters.

Krauss, M. (1992). The world's languages in crisis. Language. 68(1), 4-10.

Lee, H. Y. H. (2019). Rethinking globalization, English and multilingualism in Thailand: A Report on a five-year ethnography. 3L: Language, Linguistics, Literature ${ }^{\circledR}$. 25(1), 69-84

Lewis, G., Jones, B. \& Baker, C. (2012). Translanguaging: Developing its conceptualization and contextualization. Educational Research and Evaluation: An International Journal on Theory and Practice. 18, 655-670.

Li, H. P. \& Chen, H. C. (2019). Intelligibility and comprehensibility of the Filipino English accent to Hong Kong English speakers. 3L: Language, Linguistics, Literature ${ }^{\circledR}$. 25(1), 23-42.

Luciana. (2014). Code-switching in Indonesian radio and television programs: Linguistic and sociolinguistic perspectives. Asian Englishes. 9(1), 4-23.

Margana, M. (2013). Alih kode dalam pembelajaran Bahasa Inggris di SMA [Code-switching in English language learning in senior high schools]. LITERA. 12(1), 39-52.

Martin-Anatias, N. (2018). Bahasa gado-gado: English in Indonesian popular texts. World Englishes. 1-6.

Martínez, R., Hikida, M. \& Durán, L. (2014). Unpacking ideologies of linguistic purism: How dual language teachers make sense of everyday translanguaging. International Multilingual Research Journal. 9(1), 2642.

Mazzaferro, G. (2018). Language maintenance and shift within new linguistic minorities in Italy: a translanguaging perspective. In Mazzaferro, G. (Ed.). Translanguaging as Everyday Practice (pp. 87-106). Cham: Springer International.

May, S. (2014). Introducing the 'multilingual turn'. In May, S. (Ed.). The multilingual turn: Implications for SLA, TESOL and bilingual education (pp. 1-6). New York: Routledge. 
Murphy, J. (2014). Intelligible, comprehensible, non-native models in SL/EFL pronunciation teaching. System. $42(2), 258-269$.

Musgrave, S. (2014). Language shift and language maintenance in Indonesia. In Sercombe, P. \& Tupas, R. (Eds.). Language, education and nation building: Assimilation and shift in Southeast Asia (pp. 87-105). London: Palgrave Macmillan.

Myers-Scotton, C. (1993). Social motivations for codeswitching: Evidence from Africa. Oxford: Clarendon Press.

Myers-Scotton, C. \& Bolonyai, A. (2001). Calculating speakers: Codeswitching in a rational choice model. Language in Society. 30(1), 1-28.

Nguyen, T. T. T. (2019). Translanguaging as trans-identity: The case of ethnic minoritized students in Vietnam. Lingua. 222, 39-52.

Nguyen, T. T. T. \& Hamid, M. O. (2021). Language choice of Vietnamese ethnic minoritized students in family and community interactions: implications for minoritized language maintenance. International Multilingual Research Journal. 1-15.

Otheguy, R., García, O. \& Reid, W. (2015). Clarifying translanguaging and deconstructing named languages: A perspective from linguistics. Applied Linguistics Review. 6(3), 281-307.

Poedjosoedarmo, G. (2006). The effect of Bahasa Indonesia as a lingua franca on the Javanese system of speech levels and their functions. International Journal of Sociology of Language. 177, 111-121.

Rasman, R. (2018). To translanguage or not to translanguage? The multilingual practice in an Indonesian EFL classroom. Indonesian Journal of Applied Linguistics. 7(3), 687-694.

Ravindranath, M. \& Cohn, A. (2014). Can a language with millions of speakers be endangered? Journal of the Southeast Asian Linguistics Society. 7, 64-75.

Sakhiyya, Z. \& Martin-Anatias, N. (2020). Reviving the language at risk: a social semiotic analysis of the linguistic landscape of three cities in Indonesia. International Journal of Multilingualism. 1-18.

Setiawan, S. (2020). Shifting from an ethnic language among younger generation in a metropolitan city in Indonesia. The Asian ESP Journal. 16(2), 110-129.

Sewell, A. (2016). English pronunciation models in a globalized world: Accent, acceptability and Hong Kong English. New York, NY: Routledge.

Suwarno, B. (2020). Acquisition planning for regional indigenous heritage languages in Indonesia. SAGE Open. $10(3), 1-15$.

Shin, S. J. (2004). Developing in two Languages: Korean children in America. Bristol: Multilingual Matters.

Simsons, G. F. \& Fenning, C. D. (2017). Ethnologue: Languages of the world (20 th ed.). Dallas: SIL International.

Suryadinata, L., Arifin, E. N. \& Ananta, A. (2003). Indonesia's population: Ethnicity and religion in a changing political landscape. Singapore: Institute of Southeast Asian Studies.

Vander Klok, J. (2019). The Javanese language at risk? Perspectives from an East Java village. Language Documentation \& Conservation. 13, 300-345.

Wang, L., \& A Kirkpatrick. (2013). Trilingual education in Hong Kong primary schools: A case study. International Journal of Bilingual Education and Bilingualism. 16(1), 100-116.

Wang, D. (2019). Translanguaging in Chinese foreign language classrooms: Students and teachers' attitudes and practices. International Journal of Bilingual Education and Bilingualism. 22(2), 138-149.

Wei, L. (2011). Moment analysis and translanguaging space: Discursive construction of identities by multilingual Chinese youth in Britain. Journal of pragmatics. 43(5), 1222-1235.

Yin, R. K. (2011). Applications of case study research. London: Sage.

Yu, S. (2005). Family factors in bilingual children's code-switching and language maintenance: A New Zealand case study. PhD thesis, Auckland University of Technology, Auckland.

Yusuf, Y. Q., Fata, I. A. \& Chyntia. (2018). Types of Indonesian-English code-switching employed in a novel. Kasetsart Journal of Social Sciences. 1-6.

Zein, S. (2018). English, multilingualism and globalisation in Indonesia: A love triangle: Why Indonesia should move towards multilingual education. English Today. 1-6.

Zein, S. (2020). Language policy in superdiverse Indonesia. New York: Routledge.

Zentz, L. (2015). "Love" the local,"use" the national,"study" the foreign: Shifting Javanese language ecologies in (post-) modernity, postcoloniality and globalization. Journal of Linguistic Anthropology. 24(3), 339-359.

Zen, E. L. (2021). Javanese language as an ethnic identity marker among multilingual families in Indonesia. Linguistik Indonesia. 39(1), 49-62. 